Article

\title{
Copper- and Nitrogen-Codoped Graphene with Versatile Catalytic Performances for Fenton-Like Reactions and Oxygen Reduction Reaction
}

\author{
Xiuxiang Liao ${ }^{1,2}$, Xiaobo Wang ${ }^{1}$, Cuiyu Huang ${ }^{1}$ and Lihua Zhu ${ }^{1, *}$ \\ 1 College of Chemistry and Chemical Engineering, Huazhong University of Science and Technology, \\ Wuhan 430074, China; xiuxiang_liao@yeah.net (X.L.); wangxb@hust.edu.cn (X.W.); \\ cuiyu_huang@yeah.net (C.H.) \\ 2 Guangxi Guanfan Investment Co., Ltd., Guigang 537100, China \\ * Correspondence: lhzhu63@hust.edu.cn; Tel.: +86-27-87543632
}

Received: 8 October 2020; Accepted: 7 November 2020; Published: 15 November 2020

\begin{abstract}
Copper- and nitrogen-codoped reduced graphene oxide material $(\mathrm{Cu} / \mathrm{N}-\mathrm{rGO})$ was prepared with a hydrothermal method. Its versatile catalytic performances were demonstrated toward the oxidative degradation of rhodamine $\mathrm{B}(\mathrm{RhB})$ and oxygen reduction reaction (ORR). The $\mathrm{Cu}$ and $\mathrm{N}$ codoping of graphene enhanced not only its activation ability toward $\mathrm{H}_{2} \mathrm{O}_{2}$, but also its electrocatalytic ability for ORR. It was observed that the use of $3 \% \mathrm{Cu} / \mathrm{N}-\mathrm{rGO}$ together with $40 \mathrm{mmol} \cdot \mathrm{L}^{-1} \mathrm{H}_{2} \mathrm{O}_{2}$ and $4 \mathrm{mmol} \cdot \mathrm{L}^{-1} \mathrm{Na}_{2} \mathrm{CO}_{3}$ could remove more than $94 \%$ of the added $\mathrm{RhB}\left(30 \mathrm{mg} \cdot \mathrm{L}^{-1}\right)$ in $20 \mathrm{~min}$ through a catalytic Fenton-like degradation. Quenching experiments and electron paramagnetic resonance (EPR) measurements indicated that the main reactive species generated in the catalytic oxidation process were surface-bound $\bullet \mathrm{OH}$. The modified graphene also showed good electrocatalytic activity for ORR reaction in alkaline media through a four-electron mechanism. On the electrode of $\mathrm{Cu} / \mathrm{N}-\mathrm{rGO}$, the ORR reaction exhibited an onset potential of $-0.1 \mathrm{~V}$ and a half-wave potential of $-0.248 \mathrm{~V}$, which were correspondingly close to those on a $\mathrm{Pt} / \mathrm{C}$ electrode. In comparison with a $\mathrm{Pt} / \mathrm{C}$ electrode, the $3 \% \mathrm{Cu} / \mathrm{N}-\mathrm{rGO}$ electrode showed much greater tolerance to methanol. Such outstanding catalytic properties are attributed to the abundant active sites and the synergism between $\mathrm{Cu}$ and $\mathrm{N}$ in $\mathrm{Cu} / \mathrm{N}-\mathrm{rGO}$.
\end{abstract}

Keywords: $\mathrm{Cu}-\mathrm{N}$-codoped graphene; versatile catalyst; oxidative degradation; oxygen reduction reaction

\section{Introduction}

Due to serious challenges from environmental pollution and energy shortages, various catalysts have been developed to enhance the related pollutant degradation reactions and energy conversion reactions, especially for Fenton-like reactions, and hydrogen evolution and oxygen reduction reactions [1-5]. Typical investigations are focused on the designs of heterogeneous catalysts with high catalytic activity and selectivity by using noble metals ( $\mathrm{Pt}$ and $\mathrm{Au})$ [6,7], metal oxides $\left(\mathrm{Fe}_{3} \mathrm{O}_{4}\right.$ and $\left.\mathrm{ZnO} / \mathrm{Co}_{3} \mathrm{O}_{4}\right)[8,9]$, and metal nitrides [10]. These catalysts may have the demerits of either high cost (due to noble metals) or poor durability (due to the less noble metals), which are unfavorable to their large-scale deployment. To overcome this problem, it is interesting and important to develop carbon-based versatile catalysts that have good catalytic performances for both the Fenton-like reactions (in the field of environmental chemistry) and electrochemical oxygen reduction reaction (in the field of energy chemistry).

In fact, carbon-based catalytic materials have recently attracted much attention, such as carbon nanotubes (CNTs) [11,12], graphene [13,14], graphitic carbon nitride $\left(\mathrm{g}-\mathrm{C}_{3} \mathrm{~N}_{4}\right)[15-17]$, and carbon 
nanospheres [18,19]. For example, Peng et al. [11] illustrated that CNTs could effectively accelerate the decomposition of $\mathrm{H}_{2} \mathrm{O}_{2}$ via a nonradical activation mechanism. Kannan and Kumar [13] reviewed the current status in the design and development of graphene-based oxygen reduction reaction (ORR) catalysts for microbial fuel cell applications. Cui et al. [15] demonstrated a g- $\mathrm{C}_{3} \mathrm{~N}_{4}$ catalyst that activated $\mathrm{H}_{2} \mathrm{O}_{2}$ to generate reactive hydroxyl radicals and had good Fenton-like catalytic performance in the visible-light-driven degradation of contaminants. Mahajan et al. [18] developed a grape-like carbon nanosphere as photocatalyst and electrocatalyst, which activated the formation of oxidizing radical species under UV-light irradiation and exhibited excellent electrocatalytic activity, respectively. Heteroatom doping of metal $(\mathrm{Fe}, \mathrm{Cu}, \mathrm{Co})$ or non-metal $(\mathrm{N}, \mathrm{S}, \mathrm{B})$ in carbon may also enhance the catalytic performances [2,20-24]. The $\mathrm{N}$ atom, as an electron donor, provides electron carriers and decreases the band gap energy, which is used to dope into carbon $[21,23,25]$. The $\mathrm{N}$-doped carbon catalysts are applied to the field of catalysis. Wang et al. [23] developed N-doped graphene as Fenton-like catalysts, which efficiently catalyze the activation of persulfates for the destruction of organic contaminants. Qu et al. [25] reported N-doped graphene as metal-free electrodes for ORR, which presented much better electrocatalytic activity. Another way of improving the catalytic performances of carbon is to fabricate composites of carbon with other components. Tang and Wang used $\mathrm{Fe}_{3} \mathrm{O}_{4}$ /multiple-walled carbon nanotubes(MWCNT) composites to activate $\mathrm{H}_{2} \mathrm{O}_{2}$ for the degradation of sulfamethazine, in which MWCNTs have a rich surface area for adsorbing pollutants and for the circulation of $\mathrm{Fe}^{\mathrm{II}} / \mathrm{Fe}^{\mathrm{III}}$ [26]. These authors also fabricated the Fe@MesoC catalyst that the Fe-based magnetic nanoparticles embedded into mesoporous carbon [27]. The Fe@MesoC catalyst exhibited enhanced catalytic activity for sulfamethoxazole degradation.

In the doping of carbon-based materials, there are few reports on the codoping by both a metal atom and a non-metal atom. We investigated well the $\mathrm{N}$-doped graphene as a Fenton-like catalyst [23], and observed the strong effect of $\mathrm{Cu}$ species on the catalytic performances of carbonand non-carbon-based substrates [28-31]. Furthermore, previous reports suggested that some M-N/C catalysts showed better catalytic activity and stability than those containing only a single metal [5,31-33]. As an extension of our previous investigations, we aimed to develop a Cu-containing nitrogen-doped carbon composite as a versatile catalyst. In this carbon-based catalyst $(\mathrm{Cu} / \mathrm{N}-\mathrm{rGO})$, the doping of heteroatoms $\mathrm{N}$ into reduced graphene oxide (rGO) can be useful to trap and bond the $\mathrm{Cu}$ atoms, constructing the nitrogen-coordinated copper; and the transition metal related to Lewis acid could be prone to bind with $\mathrm{N}$ (Lewis base) to form a strong M-N coordination coupled with carbon, forming double active sites. By investigating its catalytic performances toward the degradation reaction and ORR, it was found that the $3 \% \mathrm{Cu} / \mathrm{N}-\mathrm{rGO}$ catalyst could not only efficiently catalyze the degradation of rhodamine $\mathrm{B}$ by $\mathrm{H}_{2} \mathrm{O}_{2}$, but also provide the electrochemical catalytic ability for ORR being close to that of the traditional Pt-C electrocatalyst.

\section{Results and Discussion}

\subsection{Characterizations of $\mathrm{Cu} / \mathrm{N}-\mathrm{r} \mathrm{GO}$}

The morphologies of $3 \% \mathrm{Cu} / \mathrm{N}-\mathrm{rGO}$ and $100 \% \mathrm{Cu} / \mathrm{N}$-rGO were observed by transmission electron microscopy (TEM). As shown in Figure 1a, 3\% $\mathrm{Cu} / \mathrm{N}-\mathrm{rGO}$ exhibited intrinsic graphene structures, which were composed of crumpled wave-like layers. It was evident that no copper species particles were observed due to its low-content $\mathrm{Cu}$ doping. Even at high magnification $(5 \mathrm{~nm})$, no lattice fringes from $\mathrm{Cu}$ particles were observed (Figure $1 \mathrm{~b}$ ). When the doping content of $\mathrm{Cu}$ was increased, the TEM image of $100 \% \mathrm{Cu} / \mathrm{N}-\mathrm{rGO}$ in Figure 1c clearly reveals that $\mathrm{CuO}$ particles were dispersed on the surface of the graphene. The elemental mapping images (Figure $1 \mathrm{~d}-\mathrm{h}$ ) confirm that the $3 \% \mathrm{Cu} / \mathrm{N}-\mathrm{rGO}$ catalyst consisted of four elements, i.e., oxygen, carbon, nitrogen, and copper. The evenly distributed strong signals of $\mathrm{Cu}$ and $\mathrm{N}$ suggested that both copper and nitrogen were successfully doped in the $3 \% \mathrm{Cu} / \mathrm{N}-\mathrm{rGO}$ material. 

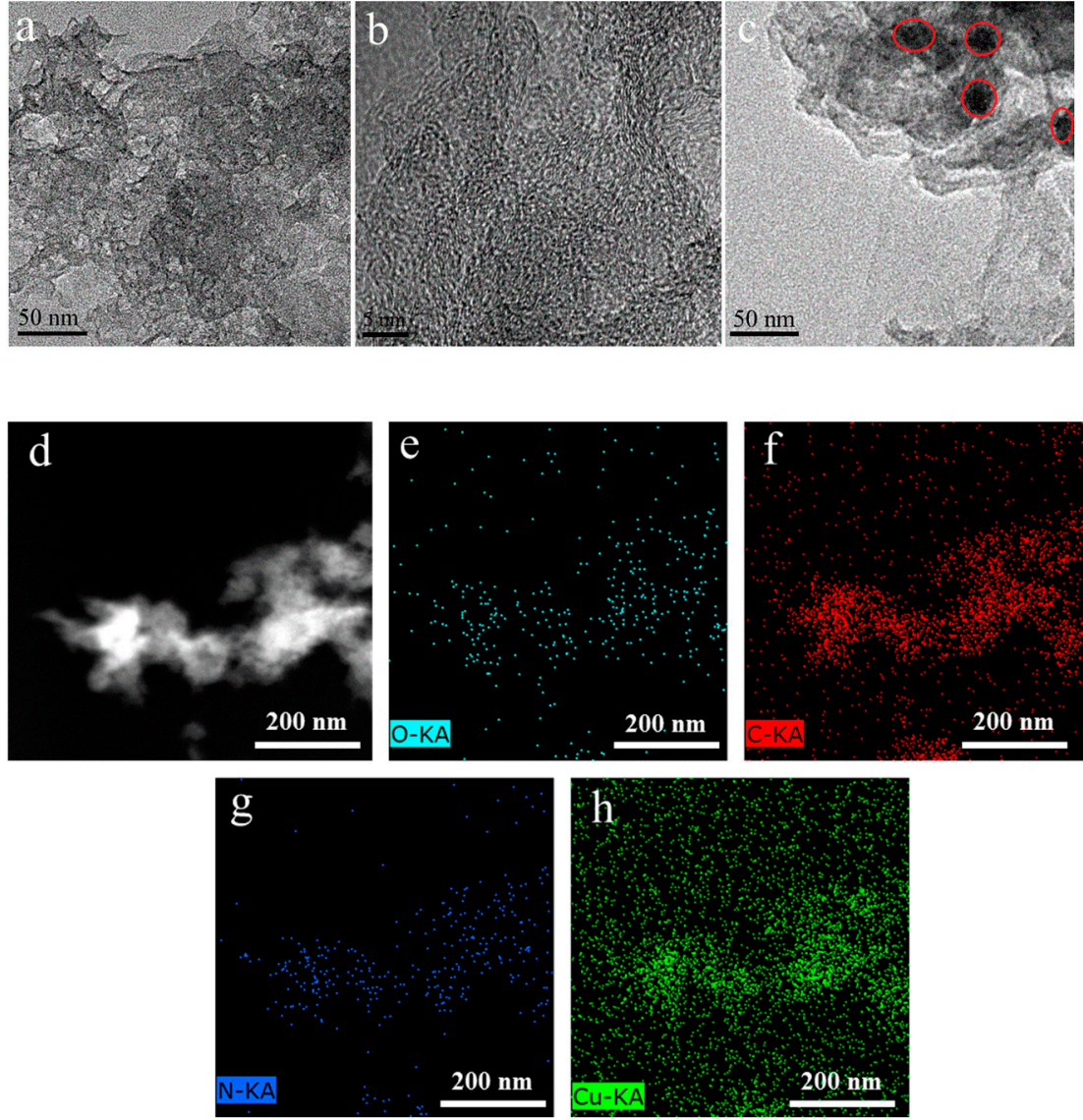

Figure 1. TEM images of (a,b) $3 \% \mathrm{Cu} / \mathrm{N}-\mathrm{rGO}$ and (c) $100 \% \mathrm{Cu} / \mathrm{N}-\mathrm{rGO}$. (d) High angular annular dark field image and elemental mapping images of (e) oxygen, (f) carbon, (g) nitrogen, and (h) copper elements of $3 \% \mathrm{Cu} / \mathrm{N}-\mathrm{rGO}$.

The X-ray diffraction (XRD) patterns of $\mathrm{rGO}, \mathrm{N}-\mathrm{rGO}, 3 \% \mathrm{Cu} / \mathrm{N}-\mathrm{rGO}$, and $100 \% \mathrm{Cu} / \mathrm{N}-\mathrm{rGO}$ are shown in Figure 2a. For all samples, two distinct characteristic peaks of the graphite (002) plane at $2 \theta=26.5^{\circ}$ and (100) plane at $2 \theta=43^{\circ}$ were observed, which demonstrated the graphitic crystal structure. However, no copper-based characteristic peaks were detected in the patterns of the $3 \% \mathrm{Cu} / \mathrm{N}-\mathrm{rGO}$ sample, due to the low $\mathrm{Cu}$ content, poor crystallinity of $\mathrm{Cu}$-based compounds, and/or the formation of $\mathrm{Cu}-\mathrm{N}$. For $100 \% \mathrm{Cu} / \mathrm{N}-\mathrm{rGO}$, new reflection peaks at $35.6^{\circ}$ and $38.9^{\circ}$ can be indexed to the $(-111)$ and (111) planes of $\mathrm{CuO}$ (JPCDS card no. 45-0937), indicating the presence of $\mathrm{CuO}$ species. This was consistent with the TEM observation.

Figure $2 \mathrm{~b}$ shows the Raman spectra of $\mathrm{rGO}, \mathrm{N}-\mathrm{rGO}, 3 \% \mathrm{Cu} / \mathrm{N}-\mathrm{rGO}$, and $100 \% \mathrm{Cu} / \mathrm{N}-\mathrm{rGO}$. In all the spectra, there were two peaks at around $1350 \mathrm{~cm}^{-1}$ and $1603 \mathrm{~cm}^{-1}$, corresponding to the $\mathrm{D}$ band and $G$ band of graphene, respectively [23]. In comparison with the $I_{D} / I_{G}$ value of $\mathrm{rGO}(1.55)$, the values of $\mathrm{N}-\mathrm{rGO}, 3 \% \mathrm{Cu} / \mathrm{N}-\mathrm{rGO}$, and $100 \% \mathrm{Cu} / \mathrm{N}-\mathrm{rGO}$ were decreased to $1.11,1.08$, and 1.10 , respectively, due to the incorporation of $\mathrm{N}$ and $\mathrm{Cu}$ atoms. This suggested the formation of the increased number of hopping defects in the graphene layers. The increased number of defect sites can be beneficial to the enhancement of the catalytic activity.

To obtain the specific surface area of rGO, $\mathrm{N}-\mathrm{rGO}, 3 \% \mathrm{Cu} / \mathrm{N}-\mathrm{rGO}$, and $100 \% \mathrm{Cu} / \mathrm{N}-\mathrm{rGO}$, we measured the adsorption-desorption isotherms of $\mathrm{N}_{2}$ (Figure S1). It was found that the pore sizes distribute mainly in the range of $2-20 \mathrm{~nm}$. The specific surface area of $3 \% \mathrm{Cu} / \mathrm{N}-\mathrm{rGO}\left(425.21 \mathrm{~m}^{2} \cdot \mathrm{g}^{-1}\right)$ was larger than that of $\mathrm{N}-\mathrm{rGO}\left(398.05 \mathrm{~m}^{2} \cdot \mathrm{g}^{-1}\right), 100 \% \mathrm{Cu} / \mathrm{N}-\mathrm{rGO}\left(186.45 \mathrm{~m}^{2} \cdot \mathrm{g}^{-1}\right)$, and rGO $\left(177.98 \mathrm{~m}^{2} \cdot \mathrm{g}^{-1}\right)$ (Table S1). The specific surface area declined when the doping context of $\mathrm{Cu}$ was $100 \%$, which may be because the $\mathrm{CuO}$ species anchored onto the surface of $100 \% \mathrm{Cu} / \mathrm{N}-\mathrm{rGO}$. 

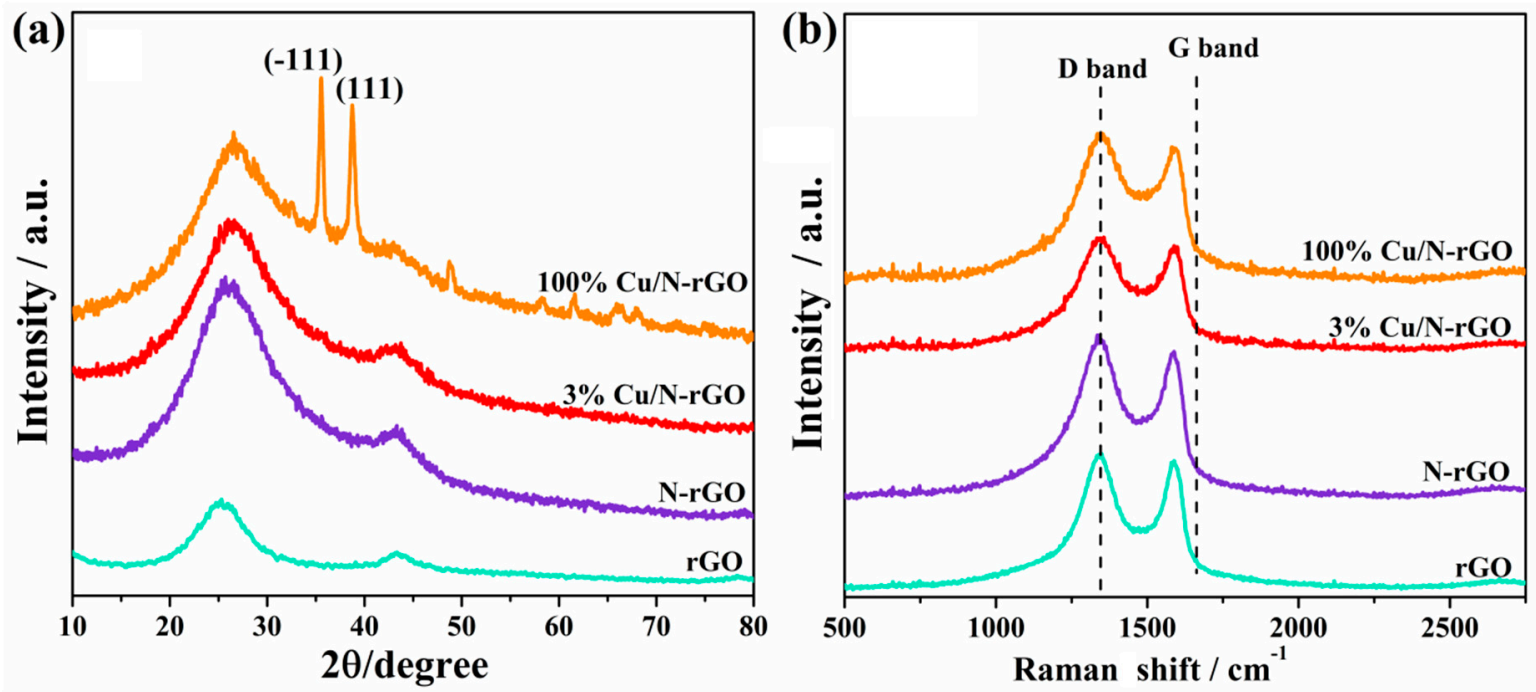

Figure 2. (a) XRD patterns and (b) Raman spectra of rGO, N-rGO, $3 \% \mathrm{Cu} / \mathrm{N}-\mathrm{rGO}$, and $100 \% \mathrm{Cu} / \mathrm{N}-\mathrm{rGO}$.

The X-ray photoelectron spectroscopy (XPS) was applied to analyze the surface chemical state of rGO, N-rGO, and 3\%Cu/N-rGO, as shown in Figure 3a. From the survey scan of $3 \% \mathrm{Cu} / \mathrm{N}-\mathrm{rGO}$, it can be seen that the $3 \% \mathrm{Cu} / \mathrm{N}-\mathrm{rGO}$ catalyst contained four kinds of elements, i.e., carbon $(70.85 \%)$, oxygen $(21.84 \%$, Table S2), nitrogen $(6.70 \%)$, and copper $(0.61 \%)$. Apparently, the metallic $\mathrm{Cu}$ signal was very weak, and the content was only $0.61 \%$. The $\mathrm{C} 1 \mathrm{~s}$ spectra (Figure $3 \mathrm{~b}$ ) of rGO, $\mathrm{N}-\mathrm{rGO}$, and $3 \% \mathrm{Cu} / \mathrm{N}-\mathrm{rGO}$ could be deconvoluted into the following bands: $\mathrm{C}=\mathrm{C} / \mathrm{C}-\mathrm{C}(284.38 \mathrm{eV})$, $\mathrm{C}=\mathrm{N} / \mathrm{C}-\mathrm{OH}(285.6 \mathrm{eV})$, epoxy C $-\mathrm{O}-\mathrm{C}(286.7 \mathrm{eV}), \mathrm{C}=\mathrm{O} / \mathrm{C}-\mathrm{N}(288.9 \mathrm{eV})$, and $\mathrm{O}-\mathrm{C}=\mathrm{O}(291.5 \mathrm{eV})$, respectively $[23,34]$. Similarly, the N 1s XPS spectra of $3 \% \mathrm{Cu} / \mathrm{N}-\mathrm{rGO}$ (Figure 3c) could be deconvoluted into three peaks around $398.3 \mathrm{eV}, 400.0 \mathrm{eV}$, and $401.2 \mathrm{eV}$, which were attributed to pyridinic-type $\mathrm{N}(47.31 \%$, Table S3), pyrrolic-type N (31.54\%), and graphitic-type N (6.76\%), respectively [23,35]. In addition, there was a particular additional peak at $399.2 \mathrm{eV}$, which was ascribed to the $\mathrm{Cu}$-coordinated nitrogen $(14.39 \%)[35,36]$. The high ratio of pyridinic $\mathrm{N}(47.31 \%$, Table S3) in $3 \% \mathrm{Cu} / \mathrm{N}-\mathrm{rGO}$ could enhance the ORR activity as compared to that of N-rGO (43.10\%) [10]; meanwhile, the Cu-coordinated nitrogen could provide new active sites. In the $\mathrm{Cu} 2 \mathrm{p}$ XPS spectrum in Figure $3 \mathrm{~d}$, the main peak between 932.1 and $934.5 \mathrm{eV}$ was similar to the values previously reported [36,37], which demonstrated that the valence states of the $\mathrm{Cu}$ species in $3 \% \mathrm{Cu} / \mathrm{N}-\mathrm{rGO}$ was situated between $\mathrm{Cu}^{0}$ and $\mathrm{Cu}^{2+}$. This result indicated that the $\mathrm{Cu}^{\delta+}(0<\delta<2)$ nature of the $\mathrm{Cu}$-coordinated nitrogen was dominant on the surface of the $\mathrm{Cu}$ species, which conforms with previous literature [38,39].

\section{2. $\mathrm{H}_{2} \mathrm{O}_{2}$ Activation Catalyzed by $\mathrm{Cu} / \mathrm{N}-r \mathrm{GO}$ for the Oxidative Degradation of Rhodamine B (RhB)}

In our previous work [23], we explored the persulfate activation ability of N-rGO toward the oxidative degradation of organic pollutants. As a green oxidizing agent, $\mathrm{H}_{2} \mathrm{O}_{2}$ is superior to persulfate because the activation of the latter disposes of unfavorable sulfates into the natural environment. Therefore, we investigated the $\mathrm{H}_{2} \mathrm{O}_{2}$ activation catalyzed by $3 \% \mathrm{Cu} / \mathrm{N}-\mathrm{rGO}$ toward the oxidative degradation of RhB. Figure 4a displays the removal of RhB in different systems. It was certain that under the tested conditions the total removal of $\mathrm{RhB}$ was contributed to from both the pre-adsorption and the followed degradation. There was no adsorption capacity in the system of $\mathrm{H}_{2} \mathrm{O}_{2}$ and $\mathrm{H}_{2} \mathrm{O}_{2}+\mathrm{Na}_{2} \mathrm{CO}_{3}$. After adding the catalysts, the adsorption capacity (Figure $4 \mathrm{~b}$ ) of these samples followed the order $3 \% \mathrm{Cu} / \mathrm{N}-\mathrm{rGO}\left(345 \mathrm{mg} \cdot \mathrm{g}^{-1}\right)>\mathrm{N}-\mathrm{rGO}\left(232 \mathrm{mg}^{-1} \mathrm{~g}^{-1}\right)>\mathrm{rGO}\left(208 \mathrm{mg} \cdot \mathrm{g}^{-1}\right)$. Therefore, the doping $\mathrm{N}$ and $\mathrm{Cu}$ improved the pre-adsorption capacity of $\mathrm{RhB}$ on $\mathrm{rGO}$, which may be attributed to more active sites and a larger specific surface area (as confirmed in Figure S1). After the pre-adsorption, the oxidative degradation of $\mathrm{RhB}$ was started by adding $\mathrm{H}_{2} \mathrm{O}_{2}$. In the absence of any catalyst, the degradation removal of $\mathrm{RhB}$ in 20 min was only $3 \%$ by adding $40 \mathrm{mM} \mathrm{H}_{2} \mathrm{O}_{2}$, and it was increased slightly to $13 \%$ by 
co-adding $4 \mathrm{mM} \mathrm{Na}_{2} \mathrm{CO}_{3}$. The enhancement induced by the introduction of $\mathrm{Na}_{2} \mathrm{CO}_{3}$ may be attributed to the greater number of free radicals originating from the interaction between $\mathrm{CO}_{3}{ }^{2-}$ and $\bullet \mathrm{OH}[40,41]$. This result was consistent with previous reports that carbonates may enhance the degradation of organic pollutants [40,42]. When N-rGO was used as the catalyst system in the presence of $\mathrm{H}_{2} \mathrm{O}_{2}$ and $\mathrm{Na}_{2} \mathrm{CO}_{3}$, $\mathrm{RhB}$ was partly degraded, giving a corresponding total $\mathrm{RhB}$ removal of $47 \%$. Surprisingly, the $\mathrm{RhB}$ removal efficiency was increased to be more than $94 \%$ when $3 \% \mathrm{Cu} / \mathrm{N}-\mathrm{rGO}$ was introduced. This improved activation performance may be ascribed to the increased number of defect sites and the synergism between $\mathrm{Cu}$ and $\mathrm{N}$ doped in $\mathrm{Cu} / \mathrm{N}-\mathrm{rGO}$. The transition metal related to Lewis acid can be prone to bind with $\mathrm{N}$ (Lewis base) to form a strong $\mathrm{M}-\mathrm{N}$ coordination coupled with carbon, which contributes to excellent catalytic activity. The nature of the metal-nitrogen species $\left(\mathrm{M}-\mathrm{N}_{\mathrm{x}}\right)$ resulted in an irregular charge distribution and distribution [20,43,44], which ameliorated the RhB adsorption and degradation. Moreover, the transition metal provided new active sites, which was beneficial to the catalytic activation because of its vacant 3D orbital and variable valence state [27].
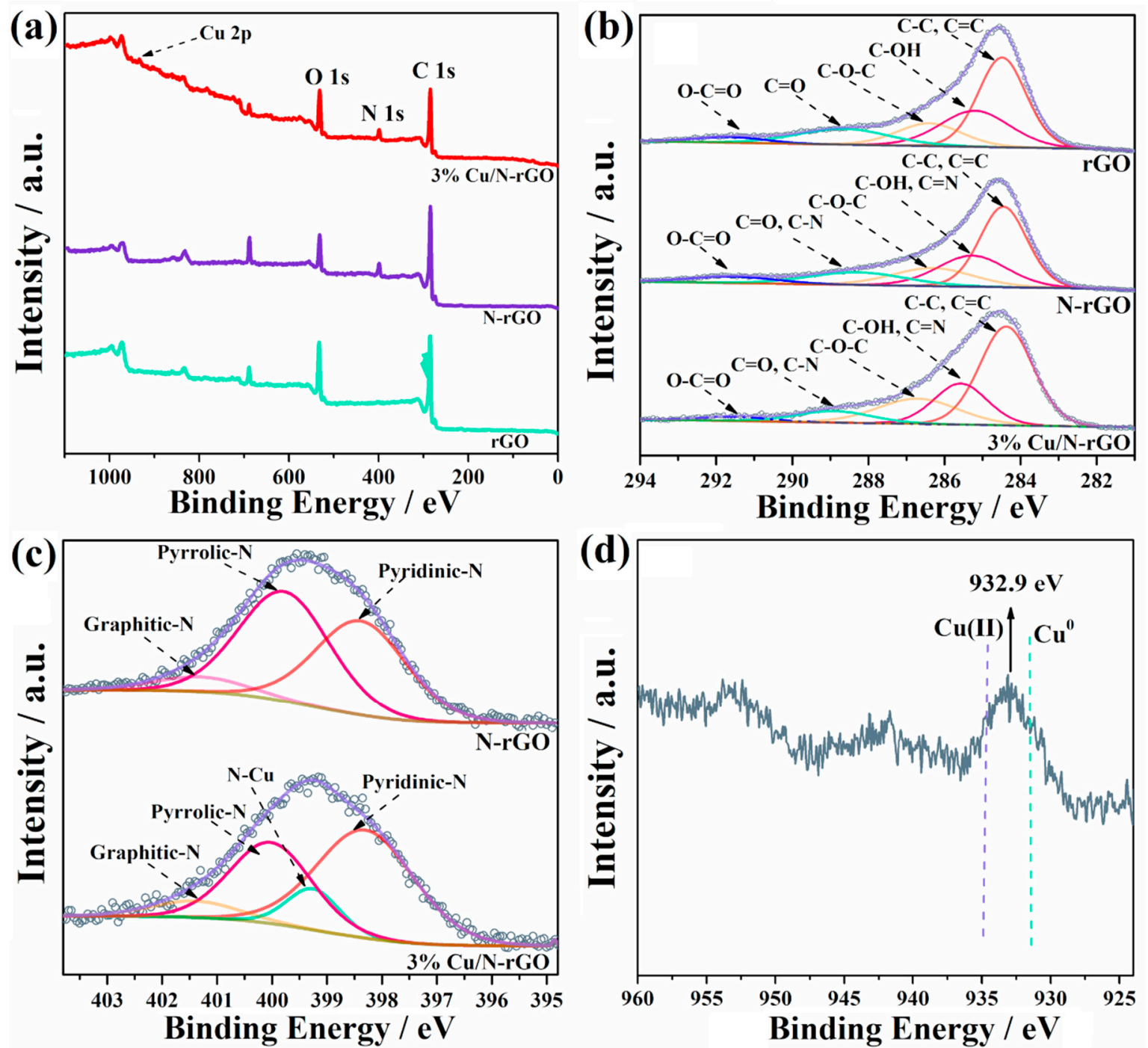

Figure 3. (a) Wide survey XPS spectra of rGO, N-rGO, and 3\%Cu/N-rGO; (b) C 1s spectra of rGO, $\mathrm{N}-\mathrm{rGO}$ and $3 \% \mathrm{Cu} / \mathrm{N}-\mathrm{rGO}$; (c) N 1s spectra of $\mathrm{N}-\mathrm{rGO}$ and $3 \% \mathrm{Cu} / \mathrm{N}-\mathrm{rGO}$; (d) $\mathrm{Cu} 2 \mathrm{p}$ of $3 \% \mathrm{Cu} / \mathrm{N}-\mathrm{rGO}$. 

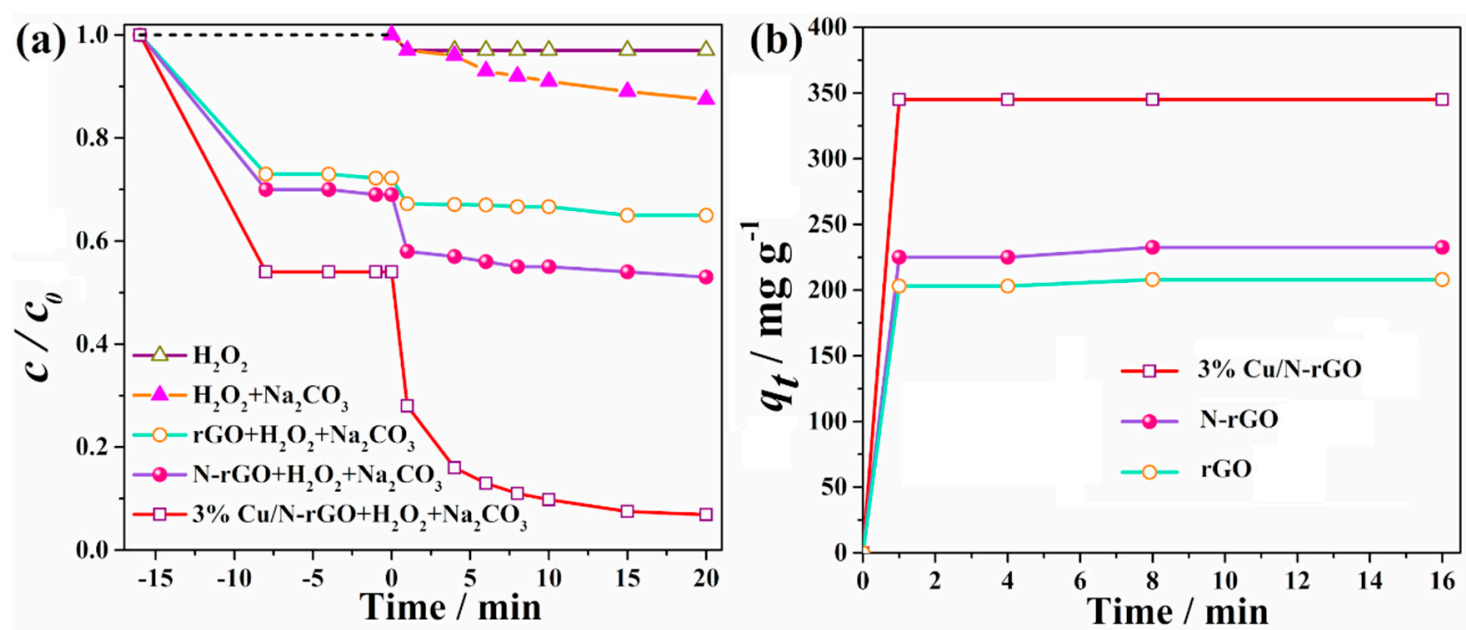

Figure 4. (a) Adsorption and degradation of $\mathrm{RhB}$ in different systems: $\mathrm{H}_{2} \mathrm{O}_{2}, \mathrm{H}_{2} \mathrm{O}_{2}+\mathrm{Na}_{2} \mathrm{CO}_{3}$, $\mathrm{rGO}+\mathrm{H}_{2} \mathrm{O}_{2}+\mathrm{Na}_{2} \mathrm{CO}_{3}, \mathrm{~N}-\mathrm{rGO}+\mathrm{H}_{2} \mathrm{O}_{2}+\mathrm{Na}_{2} \mathrm{CO}_{3}$, and $3 \% \mathrm{Cu} / \mathrm{N}-\mathrm{rGO}+\mathrm{H}_{2} \mathrm{O}_{2}+\mathrm{Na}_{2} \mathrm{CO}_{3}$. (b) Adsorption kinetics of RhB on rGO, N-rGO, and 3\%Cu/N-rGO.

Figure 5 gives the effects of various reaction parameters $\left(\mathrm{Cu}\right.$ load, $\mathrm{H}_{2} \mathrm{O}_{2}$ concentration, $\mathrm{Na}_{2} \mathrm{CO}_{3}$ concentration, and temperature) on the adsorption and degradation of $\mathrm{RhB}$ over $\mathrm{Cu} / \mathrm{N}-\mathrm{rGO}$, where the insets are the dependence of the apparent rate constant of RhB degradation on the specified reaction parameter. In order to know the practical $\mathrm{Cu}$ load in the different catalysts, we determined that the actual $\mathrm{Cu}$-doping contents of the $\mathrm{Cu} / \mathrm{N}$-rGO samples were obtained by the atomic absorption spectroscopy, as listed in Table S4. From Figure 5a, it was found that the total removal of RhB in 20 min was increased from $43 \%$ for N-rGO (zero Cu load) to $67 \%, 79 \%$, and $94 \%$ for $\mathrm{Cu}$-loading amounts of 0.5 , 1.0 , and $3.0 \mathrm{wt} . \%$, respectively. The differences in the total $\mathrm{RhB}$ removal observed between the various $\mathrm{Cu} / \mathrm{N}-\mathrm{rGO}$ catalysts were mainly attributed to the effect of the $\mathrm{Cu}$ content on the catalytic degradation of RhB. Because the degradation rate in the initial time period ( $0-1 \mathrm{~min})$ was very fast, we used only the experimental data in the initial one minute to fit with the pseudo first-reaction kinetic model. The calculated rate constant $(\mathrm{k})$ in the oxidation stage was increased from 0.11 for undoping condition to $0.16,0.25$, and $0.27 \mathrm{~min}^{-1}$ for $\mathrm{Cu}$-adding amounts of $0.5,1.0$, and $3.0 \mathrm{wt} . \%$. When the $\mathrm{Cu}$-loading amount was increased to $100 \mathrm{wt} . \%$, the $\mathrm{RhB}$ oxidative degradation was not significantly enhanced in relation to $3 \% \mathrm{Cu} / \mathrm{N}-\mathrm{rGO}$, and the apparent rate constant was only about $0.33 \mathrm{~min}^{-1}$. The above results confirmed that the degradation performance of $\mathrm{RhB}$ was best when the $\mathrm{Cu}$-loading amount was $3.0 \mathrm{wt} . \%$. The good performance of $3 \% \mathrm{Cu} / \mathrm{N}-\mathrm{rGO}$ was attributed to the moderate coordination of copper and nitrogen atoms, and then the formation of $\mathrm{Cu}-\mathrm{N}_{\mathrm{x}}(2$ or 4$)$ active sites that exhibited the strong Lewis acid-base interaction [37,45].

The effect of the initial concentration of $\mathrm{H}_{2} \mathrm{O}_{2}$ for $\mathrm{RhB}$ degradation in the $3 \% \mathrm{Cu} / \mathrm{N}-\mathrm{rGO}$ system was studied, as shown in Figure $5 \mathrm{~b}$. With increasing $\mathrm{H}_{2} \mathrm{O}_{2}$ concentrations from $5.0 \mathrm{mM}$ to $40.0 \mathrm{mM}$, the degradation efficiency improved from $73 \%$ to $94 \%$ and the $\mathrm{k}$ value increased from 0.19 to $0.27 \mathrm{~min}^{-1}$. The enhanced efficiency can be attributed to the greater generation of radical species at higher $\mathrm{H}_{2} \mathrm{O}_{2}$ concentrations. The use of $60 \mathrm{mM} \mathrm{H}_{2} \mathrm{O}_{2}$ did not further increase the degradation efficiency with a $\mathrm{k}$ value of $0.25 \mathrm{~min}^{-1}$. This was due to insufficient catalytic sites and self-quenching of the generated superfluous ${ }^{\bullet} \mathrm{OH}$. The performance of the $3 \% \mathrm{Cu} / \mathrm{N}-\mathrm{rGO}$ catalyst and the values in the previous articles are shown in Table S5. 

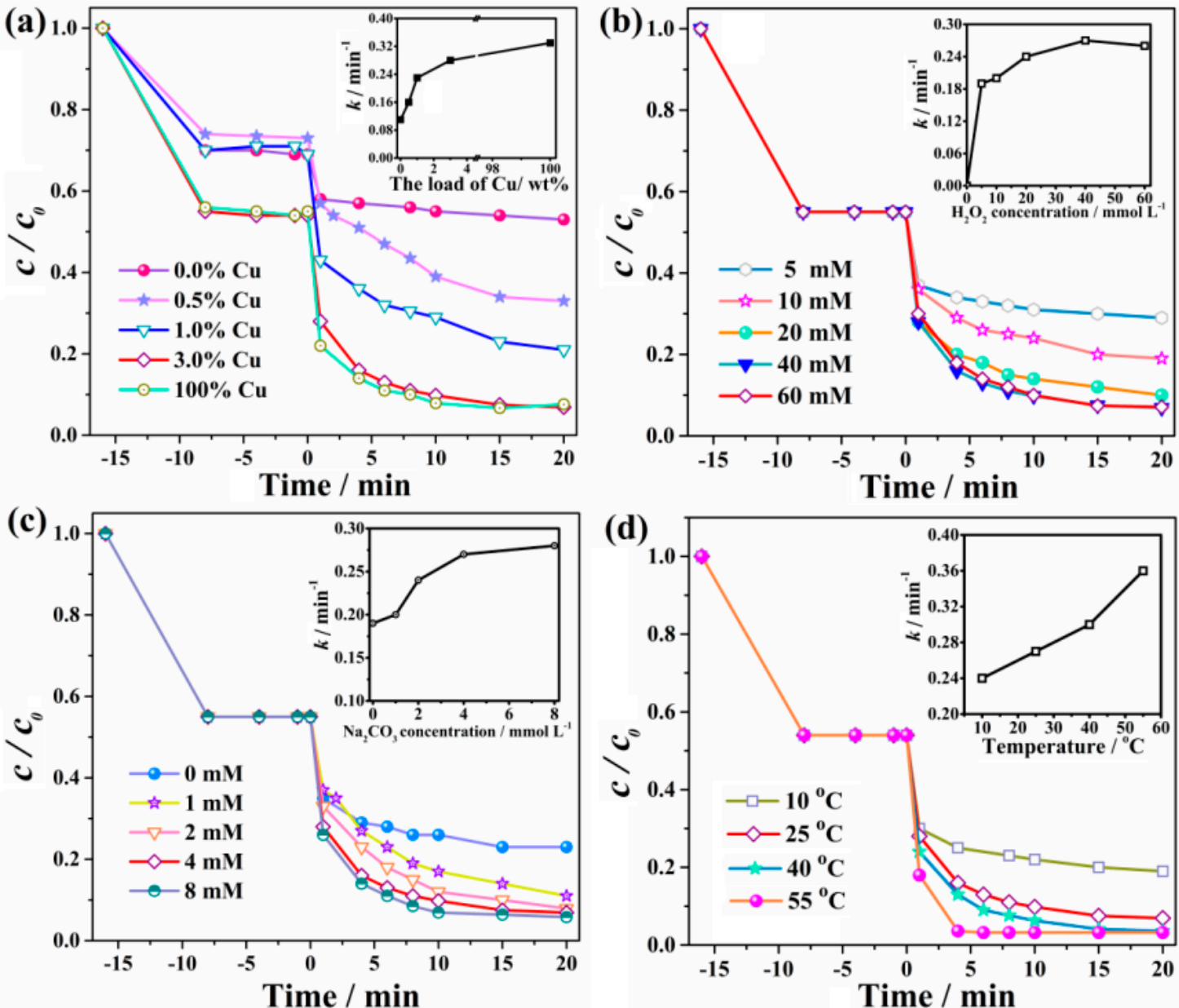

Figure 5. Effects of different reaction parameters on the adsorption and degradation of RhB over $\mathrm{Cu} / \mathrm{N}-\mathrm{rGO}$ : (a) $\mathrm{Cu}$ load, (b) $\mathrm{H}_{2} \mathrm{O}_{2}$ concentration, (c) $\mathrm{Na}_{2} \mathrm{CO}_{3}$ concentration, and (d) temperature. The insets give the dependence of the apparent rate constant of RhB degradation on the specified reaction parameter.

Figure $5 \mathrm{c}$ displays the effect of $\mathrm{Na}_{2} \mathrm{CO}_{3}$ on the catalytic degradation of $\mathrm{RhB}$. It was easily observed that the $\mathrm{k}$ value increased from 0.19 to $0.27 \mathrm{~min}^{-1}$ with the increasing $\mathrm{Na}_{2} \mathrm{CO}_{3}$ concentrations from 0 to $4 \mathrm{mM}$, but the addition of $8 \mathrm{mM} \mathrm{Na}_{2} \mathrm{CO}_{3}$ induced little further enhancement of the RhB degradation. It seemed that $4 \mathrm{mM} \mathrm{Na}_{2} \mathrm{CO}_{3}$ was optimal. This was explained by the fact that the co-existence of the $\mathrm{H}_{2} \mathrm{O}_{2}$ molecules and carbonate radicals resulted in the generation of $\mathrm{CO}_{3}{ }^{-\bullet}$, which triggered a series of reactions to generate other radicals (including the superoxide ion and singlet oxygen) for pollutant degradation as suggested by the equations below [40,41], involving the following reactions:

$$
\begin{gathered}
\mathrm{H}_{2} \mathrm{O}_{2}+\mathrm{H}_{2} \mathrm{O}+\mathrm{CO}_{3}^{-\bullet} \rightarrow \mathrm{H}_{2} \mathrm{O}+\mathrm{HCO}_{4}^{-} \\
\mathrm{H}_{2} \mathrm{O}_{2}+\mathrm{CO}_{3}^{-\bullet} \rightarrow \mathrm{HCO}_{3}^{-}+\mathrm{HO}_{2}{ }^{-} \\
\mathrm{HO}_{2}{ }^{\bullet} \rightarrow \mathrm{H}^{+}+\mathrm{O}_{2}{ }^{-} \\
\mathrm{O}_{2}^{\bullet-}+\cdot{ }^{\bullet} \mathrm{OH} \rightarrow \mathrm{O}_{2}{ }^{1}+\mathrm{HO}^{-} \\
\mathrm{HO}_{2}{ }^{\bullet}+\mathrm{O}_{2}{ }^{\bullet-} \rightarrow \mathrm{O}_{2}{ }^{1}+\mathrm{HO}_{2}^{-} \\
\mathrm{HO}_{2}{ }^{\bullet}+\mathrm{HO}_{2}{ }^{\bullet} \rightarrow \mathrm{O}_{2}{ }^{1}+\mathrm{H}_{2} \mathrm{O}_{2} \\
\mathrm{H}_{2} \mathrm{O}_{2}+\mathrm{HCO}_{3}^{-} \rightarrow \mathrm{H}_{2} \mathrm{O}+\mathrm{HCO}_{4}^{-}
\end{gathered}
$$


The degradation of $\mathrm{RhB}$ over $3 \% \mathrm{Cu} / \mathrm{N}-\mathrm{rGO}$ was investigated at temperatures in the range of $10-55{ }^{\circ} \mathrm{C}$, as shown in Figure $5 \mathrm{~d}$. The $\mathrm{k}$ value was roughly linearly increased from $0.24 \mathrm{~min}^{-1}$ to $0.36 \mathrm{~min}^{-1}$ with increasing temperatures from $10{ }^{\circ} \mathrm{C}$ to $55{ }^{\circ} \mathrm{C}$. The activation energy $\left(E_{a}\right)$ of the degradation of $\mathrm{RhB}$ in the $3 \% \mathrm{Cu} / \mathrm{N}-\mathrm{rGO}-\mathrm{H}_{2} \mathrm{O}_{2}-\mathrm{Na}_{2} \mathrm{CO}_{3}$ system was calculated according to the Arrhenius equation of $\operatorname{lnk}=\ln \mathrm{A}-\mathrm{E}_{\mathrm{a}} / \mathrm{RT}$, where $\mathrm{R}$ is the universal gas constant $\left(8.314 \mathrm{~J} \cdot \mathrm{mol}^{-1}\right)$. The $E_{a}$ value was obtained as $6.93 \mathrm{~kJ} \cdot \mathrm{mol}^{-1}$, indicating the high catalytic activity of $3 \% \mathrm{Cu} / \mathrm{N}-\mathrm{rGO}$.

It was reported ${ }^{\bullet} \mathrm{OH},{ }^{\bullet} \mathrm{O}_{2}{ }^{-} / \mathrm{HO}_{2}{ }^{\bullet}$, and singlet oxygen $\left({ }^{1} \mathrm{O}_{2}\right)$ could be generated to the reactive oxygen species for $\mathrm{RhB}$ in the $\mathrm{H}_{2} \mathrm{O}_{2}-\mathrm{Na}_{2} \mathrm{CO}_{3}$ system. To determine the main free radicals for determining the degradation process, electron paramagnetic resonance (EPR) and quenching experiments were carried out. Figure 6a displays the EPR spectra of the tested catalytic system, which were typical for TEMPO (2,2,6,6-tetramethylpiperidine-1-oxyl) ${ }^{1} \mathrm{O}_{2}$, DMPO (5,5-dimethyl-1-pyrroline $\mathrm{N}$-oxide)-・ $\mathrm{OH}$, and DMPO- ${ }^{\bullet} \mathrm{O}_{2}{ }^{-} / \mathrm{HO}_{2}{ }^{\bullet}$. Strong characteristic peaks of DMPO- ${ }^{\bullet} \mathrm{OH}$ were detected, but the signals for DMPO- ${ }^{\bullet} \mathrm{O}_{2}^{-} / \mathrm{HO}_{2}{ }^{\bullet}$ were weak and no signals were observed for TEMPO- ${ }^{1} \mathrm{O}_{2}$. This suggested that ${ }^{\bullet} \mathrm{OH}$ was primarily important in the degradation process. Furthermore, thiourea, benzoquinone, and $\mathrm{NaN}_{3}$ were used as the radical scavenger for ${ }^{\bullet} \mathrm{OH},{ }^{\bullet} \mathrm{O}_{2}{ }^{-} / \mathrm{HO}_{2}{ }^{\bullet}$, and $\left({ }^{1} \mathrm{O}_{2}\right)[46,47]$, respectively. According to Figure $6 \mathrm{~b}$, the $\mathrm{RhB}$ degradation was inhibited significantly after adding thiourea, and the removal was decreased from $94 \%$ to $53.6 \%$. When benzoquinone or $\mathrm{NaN}_{3}$ was used as the radical scavenger in the $3 \% \mathrm{Cu} / \mathrm{N}-\mathrm{rGO} / \mathrm{H}_{2} \mathrm{O}_{2} / \mathrm{Na}_{2} \mathrm{CO}_{3}$ system, the degradation efficiency declined slightly as compared with that without adding any radical scavenger. This result illustrated that the dominant free radical was ${ }^{\bullet} \mathrm{OH}$ rather than ${ }^{\bullet} \mathrm{O}_{2}^{-} / \mathrm{HO}_{2}{ }^{\bullet}$ and ${ }^{1} \mathrm{O}_{2}$ during the catalysis process, which was consistent with the reported literature [48].
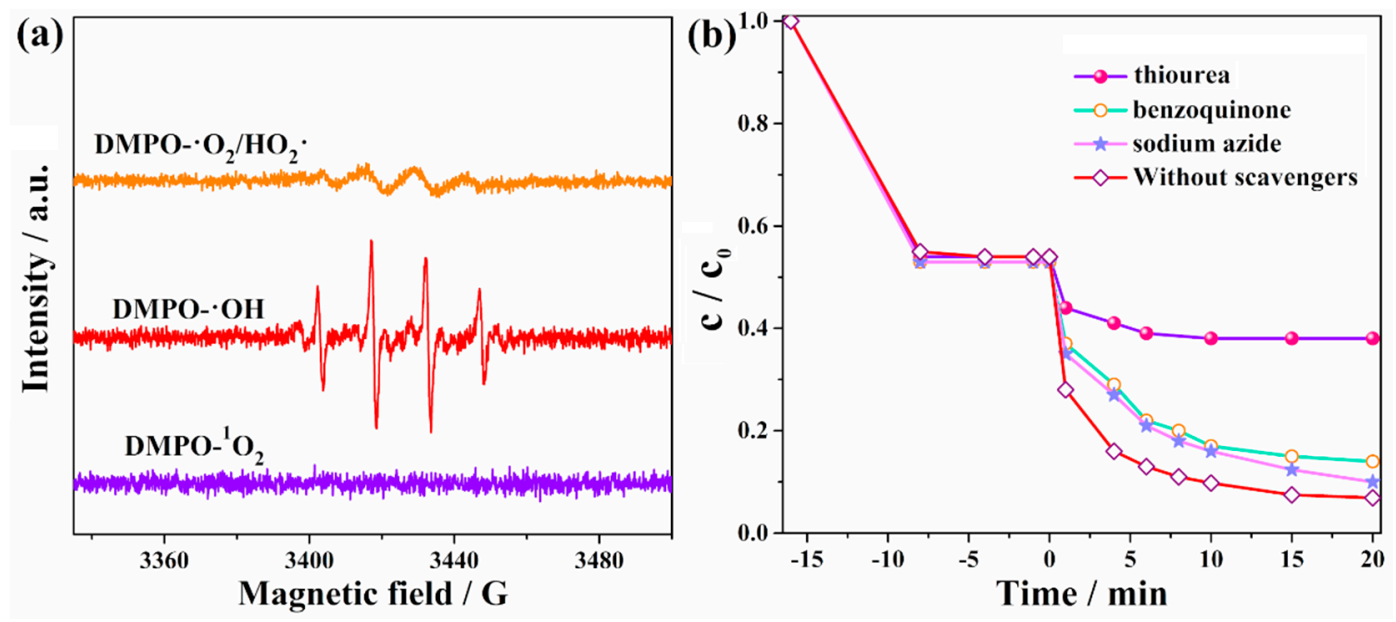

Figure 6. (a) Electron paramagnetic resonance (EPR) spectra in the systems for the degradation of RhB over $\mathrm{Cu} / \mathrm{N}-\mathrm{rGO}$, being trapped as typical DMPO- ${ }^{\bullet} \mathrm{O}_{2}{ }^{-} / \mathrm{HO}_{2}{ }^{\bullet}, \mathrm{DMPO}^{\bullet} \mathrm{OH}$, and TEMPO- ${ }^{1} \mathrm{O}_{2} \cdot(\mathbf{b})$ Effect of quenching agents on the adsorption and degradation of $\mathrm{RhB}$ for $3 \% \mathrm{Cu} / \mathrm{N}-\mathrm{rGO}$.

\subsection{Electrocatalytic Performance of $\mathrm{Cu} / \mathrm{N}-\mathrm{r} \mathrm{GO}$}

The electrocatalytic activity of 3\%Cu/N-rGO for the ORR was evaluated with cyclic voltammetry $(\mathrm{CV})$, which was conducted in $0.1 \mathrm{M} \mathrm{KOH}$ at a scan rate of $10 \mathrm{mV} \cdot \mathrm{s}^{-1}$. As shown in Figure $7 \mathrm{a}, \mathrm{b}$, the obtained cyclic voltammogram of $\mathrm{N}-\mathrm{rGO}$ and $3 \% \mathrm{Cu} / \mathrm{N}-\mathrm{rGO}$ in the $\mathrm{N}_{2}$-saturated solution was typically capacitive without an observable electrocatalytic active reaction occurring in the potential window from -1.0 to $0.2 \mathrm{~V}$ (vs. $\mathrm{Ag} / \mathrm{AgCl}$ ). However, both the electrodes of $\mathrm{N}-\mathrm{rGO}$ and $3 \% \mathrm{Cu} / \mathrm{N}-\mathrm{rGO}$ exhibited an obvious oxygen reduction peak around $-0.285 \mathrm{~V}$ in the $\mathrm{O}_{2}$-saturated electrolyte, and the peak current $\left(0.7 \mathrm{~mA} \cdot \mathrm{cm}^{-2}\right)$ on $3 \% \mathrm{Cu} / \mathrm{N}-\mathrm{rGO}$ was more than two times $\left(0.26 \mathrm{~mA} \cdot \mathrm{cm}^{-2}\right)$ that on $\mathrm{N}-\mathrm{rGO}$. This was indicative of an excellent ORR electrocatalytic activity of $3 \% \mathrm{Cu} / \mathrm{N}-\mathrm{rGO}$. To further support the result, we compared the linear sweep voltammetry (LSV) of rotating disk electrodes (RDEs) of $3 \% \mathrm{Cu} / \mathrm{N}-\mathrm{rGO}$ and other materials including $\mathrm{Pt} / \mathrm{C}$ at a rotation rate of $2500 \mathrm{rpm}$ in $\mathrm{O}_{2}$-saturated 
$0.1 \mathrm{M} \mathrm{KOH}$. As shown in Figure $7 \mathrm{c}$, these catalysts gave onset potentials $\left(\mathrm{E}_{\mathrm{onset}}\right)$ in the order of $\mathrm{Pt} / \mathrm{C}(-0.086 \mathrm{~V})>3 \% \mathrm{Cu} / \mathrm{N}-\mathrm{rGO}(-0.1 \mathrm{~V})>100 \% \mathrm{Cu} / \mathrm{N}-\mathrm{rGO}(-0.143 \mathrm{~V})>\mathrm{N} / \mathrm{rGO}(-0.146 \mathrm{~V})>\mathrm{rGO}$ $(-0.178 \mathrm{~V})$, half-wave potentials $\left(\mathrm{E}_{1 / 2}\right)$ in the order of $\mathrm{Pt} / \mathrm{C}(-0.163 \mathrm{~V})>3 \% \mathrm{Cu} / \mathrm{N}-\mathrm{rGO}(-0.248 \mathrm{~V})>$ rGO $(-0.31 \mathrm{~V})>100 \% \mathrm{Cu} / \mathrm{N}-\mathrm{rGO}(-0.351 \mathrm{~V})>\mathrm{N} / \mathrm{rGO}(-0.365 \mathrm{~V})$, and limiting current density in the order of $3 \% \mathrm{Cu} / \mathrm{N}-\mathrm{rGO}\left(-6.83 \mathrm{~mA} \cdot \mathrm{cm}^{-2}\right)>\mathrm{Pt} / \mathrm{C}\left(-6.34 \mathrm{~mA} \cdot \mathrm{cm}^{-2}\right)>100 \% \mathrm{Cu} / \mathrm{N}-\mathrm{rGO}\left(-5.18 \mathrm{~mA} \cdot \mathrm{cm}^{-2}\right)>$ $\mathrm{N} / \mathrm{rGO}\left(-4.78 \mathrm{~mA} \cdot \mathrm{cm}^{-2}\right)>\mathrm{rGO}\left(-3.34 \mathrm{~mA} \cdot \mathrm{cm}^{-2}\right)$. These results were close to or higher than the values previously reported in the literature (Table S6). It should be mentioned that both the much higher limiting current density and more positive onset potential (and half-wave potential) of 3\%Cu/N-rGO proved that the electrocatalytic activity of $3 \% \mathrm{Cu} / \mathrm{N}-\mathrm{rGO}$ was much better than $100 \% \mathrm{Cu} / \mathrm{N}-\mathrm{rGO}, \mathrm{rGO}$, and $\mathrm{N}-\mathrm{rGO}$, and very close to that of $\mathrm{Pt} / \mathrm{C}$, indicating that the existence of $\mathrm{Cu}$ species played a key role in the catalytic activity. Such outstanding catalytic properties may be attributed to the abundant active sites and the synergism between $\mathrm{Cu}$ and $\mathrm{N}$ in the $\mathrm{Cu} / \mathrm{N}-\mathrm{rGO}$.
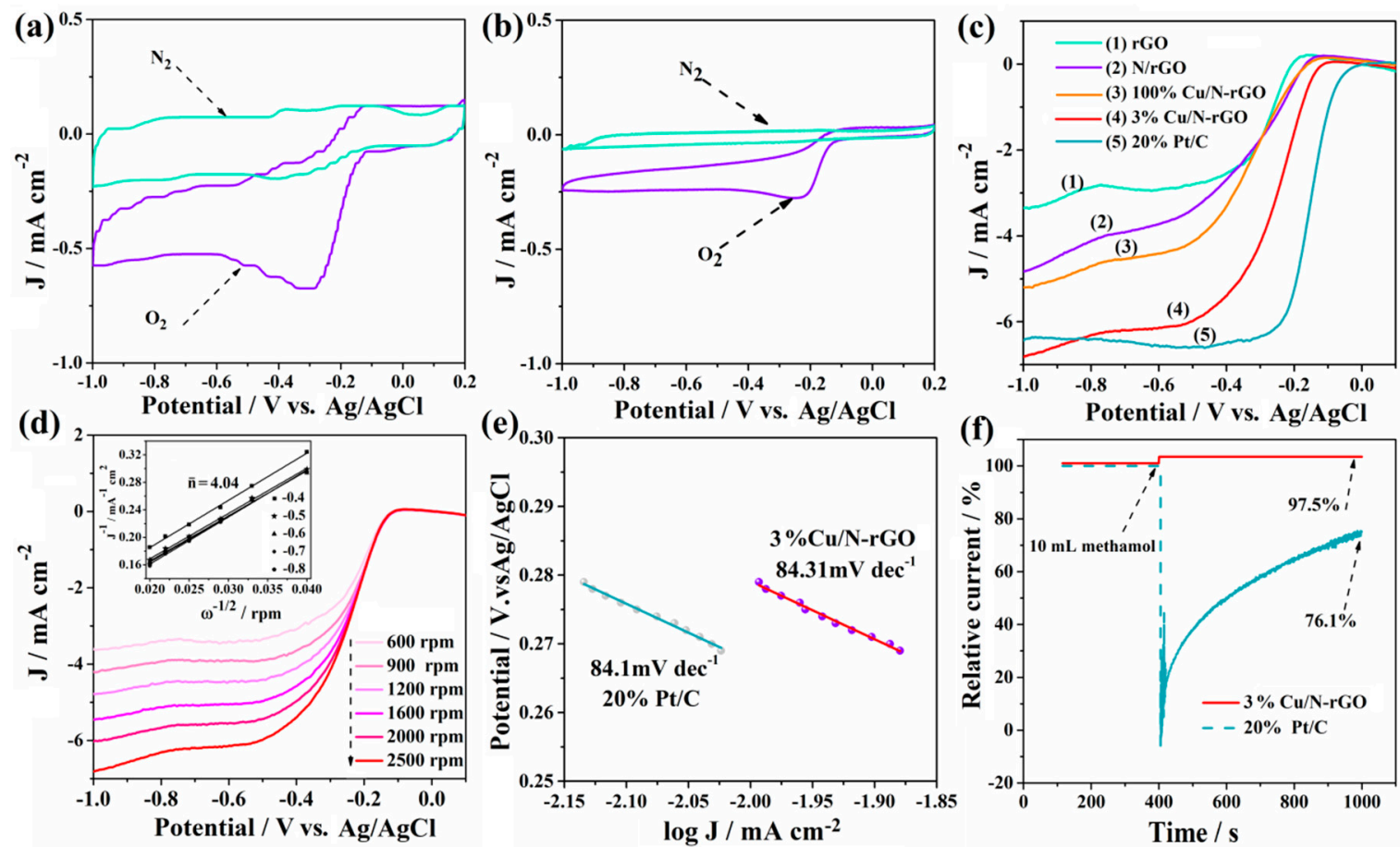

Figure 7. Cyclic voltammetry (CV) curves of (a) $3 \% \mathrm{Cu} / \mathrm{N}-\mathrm{rGO}$ and (b) $\mathrm{N}$-rGO in $\mathrm{N}_{2}$-saturated and $\mathrm{O}_{2}$-saturated in $0.1 \mathrm{M} \mathrm{KOH}$. (c) Linear sweep voltammetry (LSV) curves of the rotating electrodes of rGO, N/rGO 3\%Cu/N-rGO, 100\%Cu/N-rGO, and 20\% Pt/C at 2500 rpm. (d) LSV curves of 3\%Cu/N-rGO at different rotating rates (inset: corresponding Koutecky-Levich plots). (e) Tafel plots of 3\%Cu/N-rGO and commercial $20 \mathrm{wt} \% \mathrm{Pt} / \mathrm{C}$ in $\mathrm{O}_{2}$-saturated $0.1 \mathrm{M} \mathrm{KOH}$ at a scan rate of $10 \mathrm{mV} \cdot \mathrm{s}^{-1}$. (f) Current-time (I-t) curves of $\mathrm{Cu}-\mathrm{N} / \mathrm{C}$ and $\mathrm{Pt} / \mathrm{C}$ at $0.55 \mathrm{~V}$ in $0.1 \mathrm{M} \mathrm{KOH}$ after addition of $10 \mathrm{~mL}$ methanol.

The kinetics of ORR reaction pathways of various catalysts were studied by LSV. The LSV curves (Figure $7 \mathrm{~d}$ ) of the $3 \% \mathrm{Cu} / \mathrm{N}-\mathrm{rGO}$ catalyst illustrated that the current densities were increased with the increasing rotation speed, which was due to the increased mass transport, considering a kinetics-controlled process of ORR. As a comparison, the LSV data of rGO, N-rGO, 100\%Cu/N-rGO, and $\mathrm{Pt} / \mathrm{C}$ are plotted in Figure S2. The corresponding Koutecky-Levich $(\mathrm{K}-\mathrm{L})$ plots showed nearly parallel fitting lines (inset of Figure 7d), validating that the transferred electron numbers per oxygen molecule in ORR were almost the same. The electron transfer number (n) of 3\%Cu/N-rGO was calculated to an average value of 4.04 , indicating a better selectivity of the $4 \mathrm{e}^{-}$pathway to directly reduce $\mathrm{O}_{2}$ to $\mathrm{H}_{2} \mathrm{O}$. However, the corresponding values (insets of Figure S2a,b) of rGO and N-rGO were 1.51 and 2.16, respectively, suggesting the presence of a less efficient $2 \mathrm{e}^{-}$pathway. For both $100 \% \mathrm{Cu} / \mathrm{N}-\mathrm{rGO}$ and $\mathrm{Pt} / \mathrm{C}$, the electron transfer number (insets of Figure S2c,d) was close to 4 . However, 
the catalysis ability of $100 \% \mathrm{Cu} / \mathrm{N}-\mathrm{rGO}$ decreased greatly compared with $3 \% \mathrm{Cu} / \mathrm{N}-\mathrm{rGO}$, due to the existence of $\mathrm{CuO}$ species.

Figure $7 \mathrm{e}$ presents the Tafel plots of $3 \% \mathrm{Cu} / \mathrm{N}-\mathrm{rGO}$ and $20 \mathrm{wt} \% \mathrm{Pt} / \mathrm{C}$. The Tafel slope value for the $3 \% \mathrm{Cu} / \mathrm{N}-\mathrm{rGO}$ catalyst was calculated to be $84.31 \mathrm{mV} \cdot \mathrm{dec}^{-1}$, which was very close to that of $\mathrm{Pt} / \mathrm{C}$ $\left(84.1 \mathrm{mV} \cdot \mathrm{dec}^{-1}\right)$. This demonstrated that it was easy to drive a larger catalytic current density at a lower overpotential and had a favorable electron transfer kinetics. In a methanol fuel cell, methanol may permeate from the anode to the cathode, leading to the poisoning and deactivation of the cathode catalyst. The durability of $3 \% \mathrm{Cu} / \mathrm{N}-\mathrm{rGO}$ was evaluated by chronoamperometric measurements into $0.1 \mathrm{M} \mathrm{KOH}$. As observed in Figure $7 \mathrm{f}$, the $3 \% \mathrm{Cu} / \mathrm{N}-\mathrm{rGO}$ catalyst still retained $97.5 \%$ of its original current after methanol (AR, 99.5\%) injection, whereas the $20 \% \mathrm{Pt} / \mathrm{C}$ displayed a dramatic decline (current loss of $23.9 \%$ ), illustrating the superior tolerance toward methanol of $3 \% \mathrm{Cu} / \mathrm{N}-\mathrm{rGO}$ comparable to that of $20 \% \mathrm{Pt} / \mathrm{C}$. The result was higher than the values previously reported in the literature (Table S6).

\section{Materials and Methods}

\subsection{Reagents and Materials}

Rhodamine $\mathrm{B}(\mathrm{RhB})$, copper nitrate trihydrate $\left(\mathrm{Cu}\left(\mathrm{NO}_{3}\right)_{2} \cdot 3 \mathrm{H}_{2} \mathrm{O}\right)$, hydrogen peroxide $\left(\mathrm{H}_{2} \mathrm{O}_{2}\right.$, 30 wt. \%), $\mathrm{Na}_{2} \mathrm{CO}_{3}(99.8 \%), \mathrm{NaNO}_{3}, \mathrm{NH}_{3} \cdot \mathrm{H}_{2} \mathrm{O}(30 \%), \mathrm{KMnO}_{4}$, and $\mathrm{H}_{2} \mathrm{SO}_{4}(98 \%)$ were bought from Sinopharm Chemical Reagent Co., Ltd. (Shanghai, China). Graphite powder was purchased from American Bay Carbon (Bay City, MI, USA). All the reagents were chemical grade or higher and used without further purification.

\subsection{Preparation of the $\mathrm{Cu} / \mathrm{N}-\mathrm{r} G \mathrm{O}$ Catalyst}

Graphene oxide (GO) was prepared according to a modified Hummers method (see Supplementary Materials for more details) [23,49], and the GO suspension was obtained by dispersing GO in deionized water. Typically, a $12.5 \mathrm{~mL}$ portion of GO $\left(4 \mathrm{mg} \cdot \mathrm{mL}^{-1}\right)$ suspension was added to $32.5 \mathrm{~mL}$ of $\mathrm{Cu}\left(\mathrm{NO}_{3}\right)_{2} \cdot 3 \mathrm{H}_{2} \mathrm{O}$ aqueous solution. Afterward, the mixture was treated by ultrasonication for $30 \mathrm{~min}$. Then, $5 \mathrm{~mL}$ of $\mathrm{NH}_{3} \cdot \mathrm{H}_{2} \mathrm{O}$ were added with magnetic stirring. The mixture was then transferred into a $100 \mathrm{~mL}$ Teflon-lined autoclave and heated at $180{ }^{\circ} \mathrm{C}$ for $6 \mathrm{~h}$. Subsequently, the black precipitates were filtrated and washed with distilled water several times. Finally, the product was dispersed in water as $\mathrm{Cu} / \mathrm{N}-\mathrm{rGO}$ dispersions. $\mathrm{N}-\mathrm{rGO}$ and $\mathrm{rGO}$ samples were similarly prepared in the absence of $\mathrm{Cu}\left(\mathrm{NO}_{3}\right)_{2} \cdot 3 \mathrm{H}_{2} \mathrm{O}$ and/or $\mathrm{NH}_{3} \cdot \mathrm{H}_{2} \mathrm{O}$, respectively. In the present work, the $\mathrm{Cu} / \mathrm{N}$-rGO catalysts were referred to as $x \% \mathrm{Cu} / \mathrm{N}-\mathrm{rGO}$, where $x$ represented the $\mathrm{Cu}^{2+} / \mathrm{GO}$ mass ratio.

\subsection{Characterizations}

The morphology and the element distribution of the catalysts were characterized by transmission electron microscopy (TEM, FEI Tecnai G2 F20, Hillsboro, TX, USA) and energy-dispersive spectroscopy (EDS) (Fei company, Hillsboro, TX, USA). X-ray diffraction (XRD) was applied to obtain the crystal structure by using an X-ray diffractometer (Bruker D8 Advance, Thermo Fisher Technology Co., Ltd, Walsham, MA, USA) under the condition of $\mathrm{Cu} \mathrm{K}_{\alpha}$ irradiation with operating voltage and current of $40 \mathrm{kV}$ and $40 \mathrm{~mA}$. The surface chemical composition and valence state were analyzed with X-ray photoelectron spectroscopy (XPS) on a VG Multilab 2000 spectrometer (Thermo Fisher Technology Co., Ltd, Walsham, MA, USA) with Al $\mathrm{K}_{\alpha}$ radiation ( $300 \mathrm{~W}$ ). Raman spectra were obtained on a Thermo Fisher DXR Raman spectrometer (Thermo Fisher Technology Co., Ltd, Walsham, MA, USA) with laser power $(532 \mathrm{~nm})$. The free radicals in the DMPO- ${ }^{\bullet} \mathrm{OH}, \mathrm{DMPO}-\mathrm{O}_{2}{ }^{-\bullet} / \mathrm{HO}_{2}{ }^{\bullet}$, and TEMPO- ${ }^{1} \mathrm{O}_{2}$ systems were trapped by electron paramagnetic resonance (EPR) spectra (Bruker, Beijing, China).

\subsection{Adsorption and Degradation Experiments}

The adsorption and catalytic degradation experiments were carried out in a $100 \mathrm{~mL}$ beaker at $298 \mathrm{~K}$. The given amount of $\mathrm{Cu} / \mathrm{N}-\mathrm{rGO}(40 \mathrm{mg} / \mathrm{L})$ was added to $50 \mathrm{~mL}$ solution of $\mathrm{RhB}(30 \mathrm{mg} / \mathrm{L})$, and the 
dispersion was magnetically stirred for $16 \mathrm{~min}$ to achieve the adsorption/desorption equilibrium between the solution and the $\mathrm{Cu} / \mathrm{N}-\mathrm{rGO}$ solid. Then, a specified amount of $\mathrm{H}_{2} \mathrm{O}_{2}+\mathrm{Na}_{2} \mathrm{CO}_{3}$ was added to the above suspension to initiate the degradation. Afterward, aliquots $(1 \mathrm{~mL})$ were sampled at given time intervals and centrifuged by using an EBA-21 centrifuge (13000 rpm) to remove $\mathrm{Cu} / \mathrm{N}-\mathrm{rGO}$. The $\mathrm{RhB}$ concentration in the supernatant was determined by monitoring its absorbance at $\lambda_{\max }=554 \mathrm{~nm}$ on a Cary 60 UV-VIS spectrophotometer (Agilent, Palo Alto, CA, USA).

\subsection{Electrochemical Measurements}

The electrocatalytic activity of $\mathrm{Cu} / \mathrm{N}-\mathrm{rGO}$ for ORR was investigated at room temperature by using a CHI 660A electrochemical station with a standard three-electrode system consisting of a rotating disk electrode with a geometric area of $0.196 \mathrm{~cm}^{2}$ coated with the catalyst, a $\mathrm{Ag} / \mathrm{AgCl}$ reference electrode (saturated with $1 \mathrm{M} \mathrm{KOH}$ ), and a Pt foil counter electrode. The primary catalyst ink was prepared by dispersing $5 \mathrm{mg}$ of $\mathrm{Cu} / \mathrm{N}$-rGO into $5 \mathrm{~mL}$ of $\mathrm{N}, \mathrm{N}$-dimethylformamide (DMF) within $50 \mu \mathrm{L}$ of $5 \%$ naphthol. The as-obtained ink was coated onto the disk electrode, yielding a catalyst loading of $0.1 \mathrm{mg} \cdot \mathrm{cm}^{-2}$. The ORR reaction of the catalyst was investigated by cyclic voltammetry $(\mathrm{CV})$ in the $\mathrm{N}_{2} / \mathrm{O}_{2}$-saturated $0.1 \mathrm{M} \mathrm{KOH}$ electrolyte solution, with a scan rate of $10 \mathrm{mV} \cdot \mathrm{s}^{-1}$. Linear sweep voltammetry (LSV) curves were measured at various rotating speeds, with a scan rate of $10 \mathrm{mV} \cdot \mathrm{s}^{-1}$ under $\mathrm{O}_{2}$ condition. The stability of the catalysts was also evaluated by acquiring current-time (I-t) curves at $0.55 \mathrm{~V}$ in $\mathrm{O}_{2}$-saturated $0.1 \mathrm{M} \mathrm{KOH}$ solution.

\section{Conclusions}

A versatile catalyst of $\mathrm{Cu}$ - and $\mathrm{N}$-codoped graphene was synthesized by a hydrothermal process. The $\mathrm{Cu}$ load in the catalyst and several other parameters were optimized in terms of the catalytic activity. It was confirmed that the $3 \% \mathrm{Cu} / \mathrm{N}-\mathrm{rGO}$ catalyst showed superior catalytic activity in the $\mathrm{H}_{2} \mathrm{O}_{2}-\mathrm{Na}_{2} \mathrm{CO}_{3}$ system. Its use achieved a total removal of $94 \%$ of the added RhB within 20 min with an apparent degradation rate constant of $0.27 \mathrm{~min}^{-1}$. Furthermore, the $3 \% \mathrm{Cu} / \mathrm{N}-\mathrm{rGO}$ catalyst was applied to oxygen reduction reaction, and displayed a four-electron pathway and excellent tolerance to methanol in ORR. The better catalytic and ORR performances were attributed to the abundant active sites and the synergism between $\mathrm{Cu}$ and $\mathrm{N}$ in the $\mathrm{Cu} / \mathrm{N}-\mathrm{rGO}$.

Supplementary Materials: The following are available online at http://www.mdpi.com/2073-4344/10/11/1326/s1; Table S1: Specific surface area and pore diameter of rGO, N-rGO, 3\%Cu/N-rGO, and 100\%Cu/N-rGO. Table S2: Elemental compositions of rGO, N-rGO, and 3\%Cu/N-rGO catalysts determined by XPS. Table S3: Relative percentage of $\mathrm{N}$ species for $\mathrm{N}-\mathrm{rGO}$ and $3 \% \mathrm{Cu} / \mathrm{N}-\mathrm{rGO}$ catalysts. Table S4: The actual Cu-doping contents of $0.5 \% \mathrm{Cu} / \mathrm{N}-\mathrm{rGO}, 1.0 \% \mathrm{Cu} / \mathrm{N}-\mathrm{rGO}, 3.0 \% \mathrm{Cu} / \mathrm{N}-\mathrm{rGO}$, and $100 \% \mathrm{Cu} / \mathrm{N}-\mathrm{rGO}$ form Atomic absorption spectroscopy. Table S5: The performance of M-N catalysts in previous articles. Table S6: ORR performances of some M-N catalysts in previous articles. Figure S1: (a) $\mathrm{N}_{2}$ adsorption/desorption isotherms and (b) pore distributions of rGO, $\mathrm{N}-\mathrm{rGO}, 3 \% \mathrm{Cu} / \mathrm{N}-\mathrm{rGO}$, and 100\%Cu/N-rGO. Figure S2: LSV curves of (a) rGO, (b) N/rGO, (c) 100\%Cu-N/rGO, and (d) $20 \% \mathrm{Pt} / \mathrm{C}$.

Author Contributions: Conceptualization, X.L., X.W., and L.Z.; methodology, X.L. and C.H.; software, X.L. and X.W.; validation, C.H. and X.W.; formal analysis, X.L., X.W., C.H., and L.Z.; investigation, X.L.; resources, X.L.; data curation, X.L. and X.W.; writing—original draft preparation, X.L. and X.W.; writing—review and editing, X.L., X.W., C.H., and L.Z.; funding acquisition, X.W. All authors have read and agreed to the published version of the manuscript.

Funding: This research was funded by the China Postdoctoral Science Foundation (2018M642850).

Acknowledgments: X.W. acknowledges the funding support from the China Postdoctoral Science Foundation (2018M642850).

Conflicts of Interest: The authors declare no conflict of interest. 


\section{References}

1. Peng, Z.; Qiu, X.; Yu, Y.; Jiang, D.; Wang, H.; Cai, G.; Zhang, X.; Dong, Z. Polydopamine coated prussian blue analogue derived hollow carbon nanoboxes with FeP encapsulated for hydrogen evolution. Carbon 2019, 152, 16-23. [CrossRef]

2. Tan, H.; Tang, J.; Kim, J.; Kaneti, Y.V.; Kang, Y.M.; Sugahara, Y.; Yamauchi, Y. Rational design and construction of nanoporous iron- and nitrogen-doped carbon electrocatalysts for oxygen reduction reaction. J. Mater. Chem. A 2019, 7, 1380-1393. [CrossRef]

3. Wang, Y.; Liu, Y.; Xu, J. Separation of hydrogen sulfide from gas phase using $\mathrm{Ce}^{3+} / \mathrm{Mn}^{2+}$-enhanced fenton-like oxidation system. Chem. Eng. J. 2019, 359, 1486-1492. [CrossRef]

4. Chen, M.; Zhang, Z.; Zhu, L.; Wang, N.; Tang, H. Bisulfite-induced drastic enhancement of bisphenol A degradation in $\mathrm{Fe}^{3+}-\mathrm{H}_{2} \mathrm{O}_{2}$ Fenton system. Chem. Eng. J. 2019, 361, 1190-1197. [CrossRef]

5. Liu, P.; Hu, Y.; Liu, X.; Wang, T.; Xi, P.; Xi, S.; Gao, D.; Wang, J. Cu and Co nanoparticle-Co-decorated N-doped graphene nanosheets: A high efficiencybifunctional electrocatalyst for rechargeable $\mathrm{Zn}$-air batteries. J. Mater. Chem. A 2019, 7, 12851-12858. [CrossRef]

6. Zheng, X.; Zhang, Z.; Meng, S.; Wang, Y.; Li, D. Regulating charge transfer over 3D Au/ZnO hybrid inverse opal toward efficiently photocatalytic degradation of bisphenol A and photoelectrochemical water splitting. Chem. Eng. J. 2020, 393, 124676. [CrossRef]

7. Su, J.; Yang, Y.; Xia, G.; Chen, J.; Jiang, P.; Chen, Q. Ruthenium-cobalt nanoalloys encapsulated in nitrogen-doped graphene as active electrocatalysts for producing hydrogen in alkaline media. Nat. Commun. 2017, 8, 14969. [CrossRef]

8. Wang, Y.; Ye, X.; Chen, G.; Li, D.; Meng, S.; Chen, S. Synthesis of $\mathrm{BiPO}_{4}$ by crystallization and hydroxylation with boosted photocatalytic removal of organic pollutants in air and water. J. Hazard. Mater. 2020, 399, 122999. [CrossRef]

9. Dias, J.A.; Arantes, V.L.; Ramos, A.S.; Giraldi, T.R.; Minucci, M.Z.; Maestrelli, S.C. Characterization and photocatalytic evaluation of $\mathrm{ZnO}-\mathrm{Co}_{3} \mathrm{O}_{4}$ particles obtained by high energy milling. Part II: Photocatalytic properties. Ceram. Int. 2016, 42, 3485-3490. [CrossRef]

10. Wang, X.R.; Liu, J.Y.; Liu, Z.W.; Wang, W.C.; Luo, J.; Han, X.P.; Du, X.W.; Qiao, S.Z.; Yang, J. Identifying the Key Role of Pyridinic-N-Co Bonding in Synergistic Electrocatalysis for Reversible ORR/OER. Adv. Mater. 2018, 30, e1800005. [CrossRef]

11. Peng, J.; Xue, J.; Li, J.; Du, Z.; Wang, Z.; Gao, S. Catalytic effect of low concentration carboxylated multi-walled carbon nanotubes on the oxidation of disinfectants with $\mathrm{Cl}$-substituted structure by a Fenton-like system. Chem. Eng. J. 2017, 321, 325-334. [CrossRef]

12. Waki, K.; Wong, R.A.; Oktaviano, H.S.; Fujio, T.; Nagai, T.; Kimoto, K.; Yamada, K. Non-nitrogen doped and non-metal oxygen reduction electrocatalysts basedon carbon nanotubes: Mechanism and origin of ORR activity. Energy Environ. Sci. 2014, 7, 1950-1958. [CrossRef]

13. Kannan, M.V.; Kumar, G.G. Current status, key challenges and its solutions in the design and development of graphene based ORR catalysts for themicrobial fuel cell applications. Biosens. Bioelectron. 2016, 77, 1208-1220. [CrossRef] [PubMed]

14. Peng, J.; Zhang, Y.; Zhang, C.; Miao, D.; Li, J.; Liu, H.; Wang, L.; Gao, S. Removal of triclosan in a Fenton-like system mediated by graphene oxide: Reaction kinetics and ecotoxicity evaluation. Sci. Total Environ. 2019, 673, 726-733. [CrossRef] [PubMed]

15. Cui, Y.; Ding, Z.; Liu, P.; Antonietti, M.; Fu, X.; Wang, X. Metal-free activation of $\mathrm{H}_{2} \mathrm{O}_{2}$ by g- $\mathrm{C}_{3} \mathrm{~N}_{4}$ under visible light irradiation for the degradation of organic pollutants. Phys. Chem. Chem. Phys. 2012, 14, 1455-1462. [CrossRef] [PubMed]

16. Dai, X.; Xie, M.; Meng, S.; Fu, X.; Chen, S. Coupled systems for selective oxidation of aromatic alcohols to aldehydes and reduction of nitrobenzene into aniline using CdS/g-C3N4 photocatalyst under visible light irradiation. Appl. Catal. B Environ. 2014, 158-159, 382-390. [CrossRef]

17. Qin, Y.; Ding, Y.; Tang, H. Highly efficient visible-light photocatalytic activity of graphitic carbon nitride prepared from melamine-thiourea molecular composite. J. Environ. Chem. Eng. 2016, 4, 4374-4384. [CrossRef]

18. Mahajan, M.; Singla, G.; Singh, K.; Pandey, O.P. Synthesis of grape-like carbon nanospheres and their application as photocatalyst and electrocatalyst. J. Solid State Chem. 2015, 232, 108-117. [CrossRef] 
19. Shen, M.; Ruan, C.; Chen, Y.; Jiang, C.; Ai, K.; Lu, L. Covalent entrapment of cobalt-iron sulfides in N-doped mesoporous carbon: Extraordinary bifunctional electrocatalysts for oxygen reduction and evolution reactions. ACS Appl. Mater. Interfaces 2015, 7, 1207-1218. [CrossRef]

20. Wu, H.; Li, H.; Zhao, X.; Liu, Q.; Wang, J.; Xiao, J.; Xie, S.; Si, R.; Yang, F.; Miao, S.; et al. Highly doped and exposed $\mathrm{Cu}(\mathrm{I})-\mathrm{N}$ active sites within graphene towards efficient oxygen reduction for zinc-air batteries. Energy Environ. Sci. 2016, 9, 3736-3745. [CrossRef]

21. Li, X.; Huang, X.; Xi, S.; Miao, S.; Ding, J.; Cai, W.; Liu, S.; Yang, X.; Yang, H.; Gao, J.; et al. Single Cobalt Atoms Anchored on Porous N-Doped Graphene with Dual Reaction Sites for Efficient Fenton-like Catalysis. J. Am. Chem. Soc. 2018, 140, 12469-12475. [CrossRef] [PubMed]

22. Yao, Y.; Chen, H.; Lian, C.; Wei, F.; Zhang, D.; Wu, G.; Chen, B.; Wang, S. Fe, Co, Ni nanocrystals encapsulated in nitrogen-doped carbon nanotubes as Fenton-like catalysts for organic pollutant removal. J. Hazard. Mater. 2016, 314, 129-139. [CrossRef] [PubMed]

23. Wang, X.; Qin, Y.; Zhu, L.; Tang, H.Q. Nitrogen-Doped Reduced Graphene Oxide as a Bifunctional Material for Removing Bisphenols: Synergistic Effect between Adsorption and Catalysis. Environ. Sci. Technol. 2015, 49, 6855-6864. [CrossRef] [PubMed]

24. Liu, H.; Zhao, Q.; Liu, J.; Ma, X.; Rao, Y.; Shao, X.; Li, Z.; Wu, W.; Ning, H.; Wu, M. Synergistically enhanced activity of nitrogen-doped carbon dots/graphene composites for oxygen reduction reaction. Appl. Surf. Sci. 2017, 423, 909-916. [CrossRef]

25. Qu, L.T.; Liu, Y.; Baek, J.B.; Dai, L.M. Nitrogen-doped graphene as efficient metal-free electrocatalyst for oxygen reduction in fuel cells. ACS Nano 2010, 4, 1321-1326. [CrossRef] [PubMed]

26. Tang, J.T.; Wang, J.L. $\mathrm{Fe}_{3} \mathrm{O}_{4}$-MWCNT Magnetic Nanocomposites as Efficient Fenton-Like Catalysts for Degradation of Sulfamethazine in Aqueous Solution. Chem. Select. 2017, 2, 10727-10735.

27. Tang, J.T.; Wang, J.L. Fenton-like degradation of sulfamethoxazole using Fe-based magnetic nanoparticles embedded into mesoporous carbon hybrid as an efficient catalyst. Chem. Eng. J. 2018, 351, 1085-1094. [CrossRef]

28. Lei, M.; Guo, S.; Wang, Z.; Zhu, L.; Tang, H. Ultrarapid and Deep Debromination of Tetrabromodiphenyl Ether over Noble-Metal-Free $\mathrm{Cu} / \mathrm{TiO}_{2}$ Nanocomposites under Mild Conditions. Environ. Sci. Technol. 2018, 52, 11743-11751. [CrossRef]

29. Lei, M.; Wang, N.; Zhu, L.; Zhou, Q.; Nie, G.; Tang, H. Photocatalytic reductive degradation of polybrominated diphenyl ethers on $\mathrm{CuO} / \mathrm{TiO}_{2}$ nanocomposites: A mechanism based on the switching of photocatalytic reduction potential being controlled by the valence state of copper. Appl. Catal. B Environ. 2016, 182, 414-423. [CrossRef]

30. Ding, Y.; Tang, H.; Zhang, S.; Wang, S.; Tang, H. Efficient degradation of carbamazepine by easily recyclable microscaled $\mathrm{CuFeO}_{2}$ mediated heterogeneous activation of peroxymonosulfate. J. Hazard. Mater. 2016, 317, 686-694. [CrossRef]

31. Wu, Q.; Wang, J.; Wang, Z.; Xu, Y.; Xing, Z.; Zhang, X.; Guan, Y.; Liao, G.; Li, X. High-loaded single Cu atoms decorated on $\mathrm{N}$ doped graphene for boosting Fenton-like catalysis under neutral pH. J. Mater. Chem. A 2020, 8, 13685-13693. [CrossRef]

32. Lin, L.; Yang, Z.K.; Jiang, Y.F.; Xu, A.W. Nonprecious Bimetallic (Fe,Mo)-N/C Catalyst for Efficient Oxygen Reduction Reaction. ACS Catal. 2016, 6, 4449-4454. [CrossRef]

33. Jiang, K.; Siahrostami, S.; Akey, A.J.; Li, Y.; Lu, Z.; Lattimer, J.; Hu, Y.; Stokes, C.; Gangishetty, M.; Chen, G.; et al. Transition-Metal Single Atoms in a Graphene Shell as Active Centers for Highly Efficient Artificial Photosynthesis. Chem 2017, 3, 950-960. [CrossRef]

34. Lin, Z.; Waller, G.; Liu, Y.; Liu, M.; Wong, C.P. Facile Synthesis of Nitrogen-Doped Graphene via Pyrolysis of Graphene Oxide and Urea, and its Electrocatalytic Activity toward the Oxygen-Reduction Reaction. Adv. Energy Mater. 2012, 2, 884-888. [CrossRef]

35. Chen, M.; Zhu, L.; Zhang, Y.; Zou, J.; Tang, H. Cobalt particles encapsulated and nitrogen-doped bamboo-like carbon nanotubes as a catalytic and adsorptive bifunctional material for efficient removal of organic pollutants from wastewater. J. Environ. Chem. Eng. 2017, 5, 5322-5330. [CrossRef]

36. Ju, W.; Bagger, A.; Hao, G.P.; Varela, A.S.; Sinev, I.; Bon, V.; Cuenya, B.R.; Kaskel, S.; Rossmeisl, J.; Strasser, P. Understanding activity and selectivity of metal-nitrogen-doped carbon catalysts for electrochemical reduction of $\mathrm{CO}_{2}$. Nat. Commun. 2017, 8, 944. [CrossRef] 
37. Qu, Y.; Li, Z.; Chen, W.; Lin, Y.; Yuan, T.; Yang, Z.; Zhao, C.; Wang, J.; Zhao, C.; Wang, X.; et al. Direct transformation of bulk copper into copper single sites via emitting and trapping of atoms. Nat. Catal. 2018, 1, 781-786. [CrossRef]

38. Galtayries, A.; Bonnelle, J.P. XPS and ISS studies on the interaction of $\mathrm{H} 2 \mathrm{~S}$ with polycrystalline $\mathrm{Cu}, \mathrm{Cu}_{2} \mathrm{O}$ and $\mathrm{CuO}$ surfaces. Surf. Interface Anal. 1995, 23, 171-179. [CrossRef]

39. Wang, Y.; Biradar, A.V.; Wang, G.; Sharma, K.K.; Duncan, C.T.; Rangan, S.; Asefa, T. Controlled Synthesis of Water-Dispersible Faceted Crystalline Copper Nanoparticles and Their Catalytic Properties. Chem. Eur. J. 2010, 16, 10735-10743. [CrossRef]

40. Li, L.; Huang, J.; Hu, X.; Zhang, S.; Dai, Q.; Chai, H.; Gu, L. Activation of sodium percarbonate by vanadium for the degradation of aniline in water: Mechanism and identification of reactive species. Chemosphere 2019, 215, 647-656. [CrossRef]

41. Zhou, L.; Song, W.; Chen, Z.; Yin, G. Degradation of Organic Pollutants in Wastewater by Bicarbonate-Activated Hydrogen Peroxide with a Supported Cobalt Catalyst. Environ. Sci. Technol. 2013, 47, 3833-3839. [CrossRef] [PubMed]

42. Bagal, M.V.; Gogate, P.R. Sonochemical degradation of alachlor in the presence of process intensifying additives. Sep. Purif. Technol. 2012, 90, 92-100. [CrossRef]

43. Huang, Z.; Pan, H.; Yang, W.; Zhou, H.; Gao, N.; Fu, C.; Li, S.; Li, H.; Kuang, Y. In Situ Self-Template Synthesis of Fe-N-Doped Double-Shelled Hollow Carbon Microspheres for Oxygen Reduction Reaction. ACS Nano 2018, 12, 208-216. [CrossRef] [PubMed]

44. Yin, P.; Yao, T.; Zheng, L.; Lin, Y.; Ju, H.; Zhu, J.; Hong, X.; Deng, Z.; Zhou, G.; Wei, S.; et al. Single Cobalt Atoms with Precise N-Coordination as Superior Oxygen Reduction Reaction Catalysts. Angew. Chem. Int. Ed. 2016, 55, 10800-10805. [CrossRef] [PubMed]

45. Ni, Y.; Chen, Z.; Kong, F.; Qiao, Y.; Kong, A.; Shan, Y. Space-confined synthesis of multilayer Cu-N doped graphene nanosheets for efficient oxygen electroreduction. Dalton Trans. 2017, 46, 8586-8592. [CrossRef] [PubMed]

46. Yan, P.; Sui, Q.; Lyu, S.; Hao, H.; Schröder, H.F.; Gebhardt, W. Elucidation of theoxidation mechanisms and pathways of sulfamethoxazole degradation under Fe(II) activated percarbonate treatment. Sci. Total Environ. 2018, 640, 973-980. [CrossRef]

47. Ge, L.; Moor, K.; Zhang, B.; He, Y.; Kim, J.H. Electron Transfer Mediation by Aqueous C60 Aggregatesin $\mathrm{H}_{2} \mathrm{O}_{2} / \mathrm{UV}$ Advanced Oxidation of Indigo Carmine. Nanoscale 2014, 6, 13579-13585. [CrossRef]

48. Du, J.; Bao, J.; Fu, X.; Lu, C.; HoonKim, S. Mesoporous sulfur-modified iron oxide as an effective Fenton-like catalyst for degradation of bisphenol A. Appl. Catal. B Environ. 2016, 184, 132-141. [CrossRef]

49. Hummer, W.; Offeman, R. Preparation of graphitic oxide. J. Am. Chem. Soc. 1958, 80, 1339-1340. [CrossRef]

Publisher's Note: MDPI stays neutral with regard to jurisdictional claims in published maps and institutional affiliations.

(C) 2020 by the authors. Licensee MDPI, Basel, Switzerland. This article is an open access article distributed under the terms and conditions of the Creative Commons Attribution (CC BY) license (http://creativecommons.org/licenses/by/4.0/). 